\title{
Assessment of physicochemical and radon- attributable radiological parameters of drinking water samples of Pithoragarh district, Uttarakhand
}

\section{Prakhar Singh}

Uttarakhand Science Education and Research Cantre

OP Nautiyal

Uttarakhand Science Education and Research Centre

Manish Joshi

Bhabha Atomic Research Centre

Ankur Kumar ( $\sigma$ physicsankur@gmail.com )

Gurukula Kangri University: Gurukula Kangri vishwavidyalaya https://orcid.org/0000-0001-8628-5702

\section{Taufiq Ahamad}

Uttarakhand Science Education nad Research Centre

Kuldeep Singh

Government Post Graduate College New Tehri

\section{Research Article}

Keywords: Annual effective dose, Groundwater, Radon activity, Spatial distribution, TDS

Posted Date: August 14th, 2021

DOI: https://doi.org/10.21203/rs.3.rs-499817/v1

License: (1) This work is licensed under a Creative Commons Attribution 4.0 International License. Read Full License

Version of Record: A version of this preprint was published at Journal of Radioanalytical and Nuclear Chemistry on October 18th, 2021. See the published version at https://doi.org/10.1007/s10967-02108056-5. 


\section{Assessment of physicochemical and radon-attributable radiological parameters of drinking water samples of Pithoragarh district, Uttarakhand}

4 Prakhar $\operatorname{Singh}^{1}$, O. P. Nautiyal ${ }^{1}$, Manish Joshi ${ }^{2}$, Ankur Kumar*3, Taufiq Ahamad ${ }^{4}$, 5

6

Kuldeep Singh ${ }^{5}$

${ }^{1}$ Uttarakhand Science Education and Research Centre, Dehradun - 248006, India ${ }^{2}$ Radiological Physics and Advisory Division, Bhabha Atomic Research Centre, Mumbai-400094, India

${ }^{3}$ Department of Physics, Gurukula Kangri Vishwavidyalaya Haridwar - 249404, India

${ }^{4}$ Department of Physics, Shri Guru Ram Rai PG College, Dehradun-248001, India ${ }^{5}$ Department of Physics, Govt. PG College, Tehri Garhwal, New Tehri-249001, India *E-mail address of the corresponding author:physicsankur@gmail.com Abstract

This study evaluates the quality of drinking water samples (sample size $=52$ ) taken from various locations of Pithoragarh district, Uttarakhand. The parameters include physiochemical properties viz. total dissolved solids (TDS in $\mathrm{mg} / \mathrm{L}$ ), electrical conductivity/salinity $(\mu \mathrm{S} / \mathrm{cm}), \mathrm{pH}$ and radiological dose attributable to radon in water $(\mu \mathrm{Sv} / \mathrm{y})$. TDS values for the tested samples varied within the range of 18-434 mg/L with average value of $148 \mathrm{mg} / \mathrm{L}$. Electrical conductivity and $\mathrm{pH}$ for these samples was measured as 36-868 $\mu \mathrm{S} / \mathrm{cm}$ (average: $296 \mu \mathrm{S} / \mathrm{cm}$ ) and 6.8-8.2 (average: 7.2), respectively. Radon activity concentration for these water samples was measured using scintillation-based radon monitor, immediately after sampling at the location site. Radon activity concentration was measured as $0.6-81.9 \mathrm{~Bq} / \mathrm{L}$ with an average value of $17.8 \mathrm{~Bq} / \mathrm{L}$. The 
24 paper also estimates the annual effective ingestion dose $(\mu \mathrm{Sv} / \mathrm{y})$, annual effective inhalation dose $25(\mu \mathrm{Sv} / \mathrm{y})$ and total effective dose $(\mu \mathrm{Sv} / \mathrm{y})$ attributable to radon in drinking water samples. Spatial 26 patterns for the observed variations have also been interpreted for the dataset obtained over the 27 terrestrial region.

\section{Keywords}

29 Annual effective dose;Groundwater; Radon activity; Spatial distribution;TDS.

\section{Introduction}

Water quality is one of the important parameters determining the health risks to humans. Measurement of various characteristics of water, associated interpretations and hazard estimations have been performed worldwide at different places of relevance. It is a fact that numerous contaminants pollute water sources and this impacts human health risks. The source of contaminants could be natural or anthropogenic and the level of degradation of water quality depends on their source-term. Radioactive contamination is also a serious issue around the globe. While the mineralogy acts as the source term for physicochemical parameters, natural radio-nuclides present in the earth crust acts as the main source for radiological impurity of ground and surface water [1]. Total dissolved solids (TDS), salinity/electrical conductivity and $\mathrm{pH}$ are three vital physicochemical parameters which vary for different water sources and also get affected due to human activities. Similar to the air matrix, radon/thoron gases and its decay products primarily released from the natural radio-active precursors (decay chains) determines the radioactivity concentration profile of water. $\mathrm{Rn}^{222}$ and $\mathrm{Rn}^{220}$ are two isotopes of radon with different half-life ( $\mathrm{Rn}^{222}$ has a half-life of 3.82 days and $\mathrm{Rn}^{220}$ has a half-life of 55.5 seconds) [2]. Due to its gaseous nature, it travels through cracks and pores between the grain in the soil and easily escape into the ground and surface water. Previous studies in other parts of Uttarakhand Himalaya indicate the presence of a significant amount of natural radioactivity in the air, soil, and water [6-12]. Pithoragarh is a high-altitude terrestrial region and groundwater is the main source of water to be used for domestic as well as industrial purposes. Most of the population in the region depends on natural spring sources for drinking water [13]. $\mathrm{Rn}^{222}$ emits alpha particles and its short-lived progenies $\left(\mathrm{Po}^{218}, \mathrm{Po}^{214}, \mathrm{~Pb}^{214}\right.$ and $\left.\mathrm{Bi}^{214}\right)$ interact with atmospheric particles.

3 concentration. [15-18]. Such measurements, their usage in the estimations of radiological doses 
and the interpretations are highlighted as an important data-base by standard international commissions. Therefore, measurement of radioactivity concentration and the estimation of radiological doses due to the ingestion of $\mathrm{Rn}^{222}$ has been done by several researchers in past as well [19-21].

This study focuses on the measurement of physicochemical properties and $\mathrm{Rn}^{222}$ concentration in drinking water samples of Pithoragarh district, Uttarakhand, India. $\mathrm{Rn}^{222}$ concentration was measured using a portable $\mathrm{Rn}^{222}$ monitor on the spot of sampling right after the sample is collected. The physicochemical properties (TDS, Electrical Conductivity, and $\mathrm{pH}$ ) were measured in the laboratory. Statistical analysis of the obtained data is discussed in detail in this work. QGIS (Quantum GIS) 3.4 Madeira LTS (Long Term Support) is used for the spatial or geological analysis of the data over the study region.

\section{Geology of Study Area}

Pithoragarh is the easternmost district of Uttarakhand state of India. It confines higher Himalayan mountain ranges, passes, valleys, alpine meadows, forests, waterfalls, rivers, glaciers, springs, and snow-capped peaks. The geographical area of Pithoragarh is 7,110 square $\mathrm{Km}$. The district is located in the Kumaun division of Uttarakhand. The northern part of the district is attached to the Tibetan plateau and Nepal is on its eastern border that is separated by the Kali river also known as Sharda river. The elevation from sea level ranges between 500 to $6400 \mathrm{~m}$. Variation of temperature is considerable from area to area depending upon the altitude. The lower Himalaya is confined by the Main Boundary Thrust (MBT) in the southern part and Main Central Thrust in the Northern part. It consists of the late Proterozoic to early Cambrian sediments intruded by some granites and volcanic rocks [22]. The rock types in this land are quartzites, siltstone, carbonates, Phyllite, schist with subordinate impure marbles, metamorphic rocks, and orthogneisses [23]. Almost $50 \%$ of the area is occupied by snowy Himalayan mountain ranges in the north forming several glaciers in the region. Therefore, at lower reaches, numerous natural springs are available for domestic and irrigation purposes. The district receives a good amount of rainfall, which infiltrates into the ground through the soil matrix and recharges the groundwater level. During the post-monsoon period, the water level reduces gradually affecting running water inventory for the pre-monsoon phase. The radon exhalation and water discharge rate are largely influenced by the meteorological parameters like pressure, 
84 temperature, relative humidity etc. Radon level in water was found to be higher in monsoon and 85 post-monsoon season in comparison to pre-monsoon season in a study conducted in Garhwal region [27]. The concentration of radon is linked to water quality in terms of radiological

87 considerations. This study was performed for the post-monsoon season only and the results are interpreted in terms of water quality characterization using the results obtained from the measurements made in this season. Whereas physicochemical properties represent the parameters mainly for post-monsoon season, annual inferences are also made for radiological dose estimations. As the radon concentration values remains in mid-level (maximum in premonsoon and minimum in monsoon period) range, these can be assumed as representing yearly averaged values for calculations.

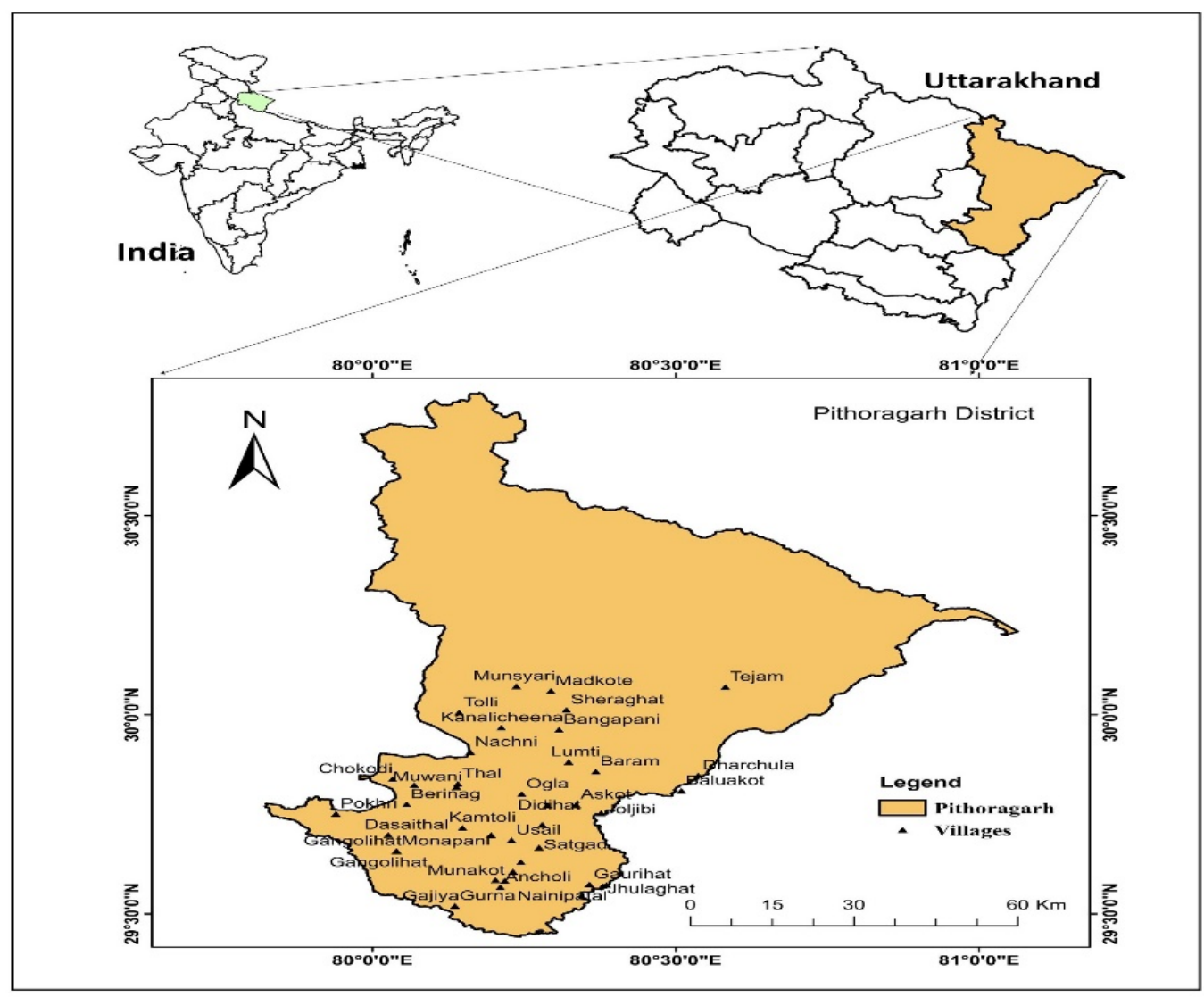
state of India).

\section{Experimental Techniques and Methodology}


52 water samples of drinking water were collected from different villages of the study area from various sources like natural springs (49) and hand pumps (3) in the month of December. Radon concentration profile follows a seasonal pattern due to the change in the water level as the function of rainfall. Radon concentration is expected to be at maximum level in the summer season while it reduces in monsoon period due to the increase in water level. The water samples that have been taken from the locations represent water which is used by the local population for domestic purpose as well as for drinking. Water samples were collected in polypropylene double capped sampling bottles. The bottles were washed thoroughly prior to sampling to reduce external contamination. Before pouring the sample into the bottles, a container is used to collect the water. The polypropylene sample bottle was then immersed into the container. One end of a polypropylene pipe is immersed into the opening of water source. After ensuring that no air bubble is forming inside the pipe, the other end of the pipe is purged into the sampling bottle, replacing the water in the sample bottle. To collect water sample from the hand-pump, the pipe was plunged inside the pumping cylinder of hand-pump up to the water level and hand-pump lever was operated to pump out water. After ensuring that there are not any bubbles forming inside the pipe, the other end of pipe then plunged inside the sample bottle that was immersed inside the water in large container. The sample bottle was capped inside the container to prevent the atmospheric contaminants. This sampling methodology was used to reduce the chance of instant degassing of radon while pumping the water out from the handpump, and to reduce external contamination from the atmosphere. After sampling, these water samples were analyzed for $\mathrm{Rn}^{222}$ on the spot with a portable $\mathrm{Rn}^{222}$ monitor. After the $\mathrm{Rn}^{222}$ measurement, water samples were taken to the laboratory for physiochemical analysis.

\section{Measurement of $\mathrm{Rn}^{222}$ concentration}

Water samples were analysed for $\mathrm{Rn}^{222}$ concentration with Smart RnDuo using a bubbler kit. Smart RnDuo is an online active $\mathrm{Rn}^{222}$ monitor that is developed by Bhabha Atomic Research centre, Mumbai. The working of Smart RnDuo is based on the alpha scintillation method. An Ag: $\mathrm{ZnS}$ coated cell (Lucas cell) is connected to a photomultiplier tube that records scintillation counts when an alpha particle hits the wall of the lucas cell [28]. The basic set-up for the measurement of radon concentration in water involves $50 \mathrm{ml}$ glass sample bottle attached to a bubbler. The bubbler is connected to the radon monitor using polypropylene pipes and a particle filter. The air pump is used to circulate the air within the sample through the Lucas cell to obtain 
escaping $\mathrm{Rn}^{222}$ from the sample inside the Lucas cell. For 15 minutes of the measurement cycle, a pump is set to on for 5 minutes and for the rest 10 minutes, the alpha count continues. After completing one cycle, average $\mathrm{Rn}^{222}$ activity concentration is displayed on the monitor. Figure 2 shows the schematic diagram for the setup for the measurement of $\mathrm{Rn}^{222}$ activity concentration using the bubbler method [29]. This instrument gives $\mathrm{Rn}^{222}$ concentration in the air volume having unit $\mathrm{Bq} / \mathrm{m}^{3}$. To calculate $\mathrm{Rn}^{222}$ activity concentration in water volume (liquid) one can use the following equation 1 for the setup [30].

$$
C_{l i q}=C_{a i r}\left[K+\frac{V_{a i r}}{V_{l i q}}\right]
$$

Where $C_{\text {air }}$ is the $\mathrm{Rn}^{222}$ activity concentration of air given by the $\mathrm{Rn}^{222}$ monitor, $\mathrm{K}$ is the partition coefficient (i.e. $K=0.25$ for water and air), $V_{\text {air }}$ and $V_{\text {liq }}$ is the volume of airpresent in the setup and volume of liquid sample present in the sampling bottle, respectively.

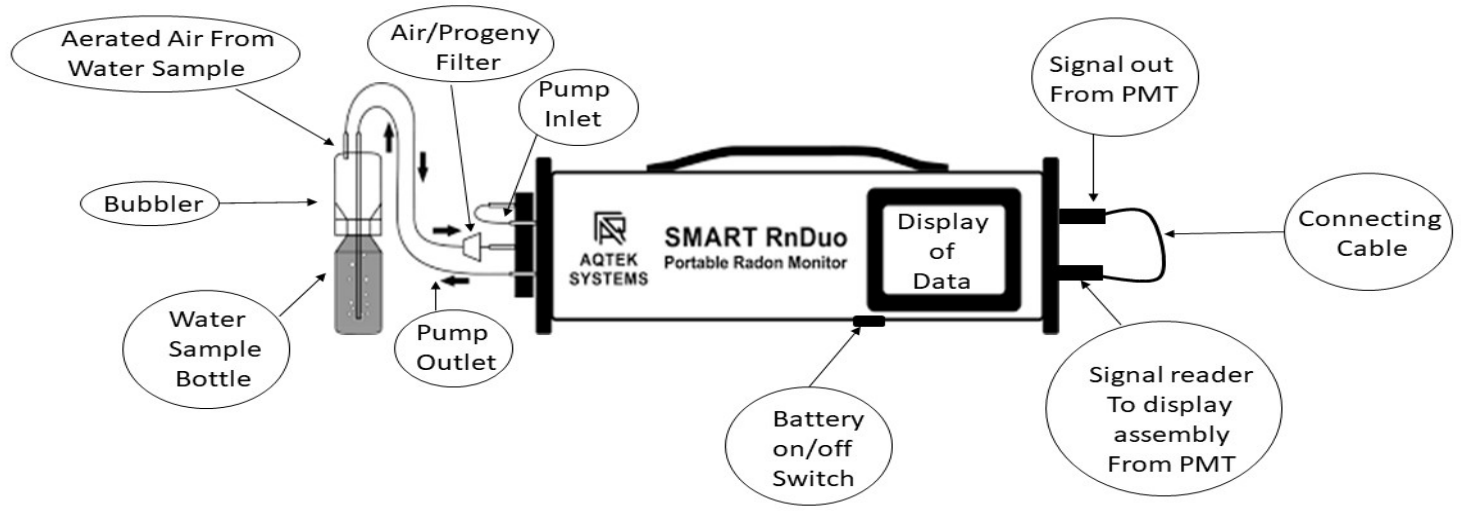

Figure 2: Schematic diagram of measurement of $R n^{222}$ activity concentration using bubbler kit attached to portable Smart RnDuo active radon monitor.

\section{Measurement of Physiochemical parameters}

The measured physiological parameters for the water samples i.e., Total Dissolved Solids (TDS), $\mathrm{pH}$, and electrical conductivity due to salinity were measured using standard analytical methods available at Nuclear Research Laboratory, USERC, Dehradun. The Oakton CON 550 Benchtop Conductivity/TDS meter kit was used for the measurement of TDS and Electrical Conductivity of the water samples. The instrument measure electrical conductivity/TDS though a conducting probe, and has conductivity measuring range of $0-200 \mathrm{mS} / \mathrm{cm}$ with an accuracy of $\pm 1.0 \%$ fullscale \pm 1 digit, and TDS measuring range of $0-100 \mathrm{~g} / \mathrm{L}$ with a resolution of $0.1 / 1 \mathrm{mg} / \mathrm{L}$. TDS is the 
153

154

155

156

157

158

159

160

161

162

163

164

165

166

167

168

169

170

171

172

173

174

175

176

177

178

179

180

181

81

measurement of the total weight of solids dissolved in the water sample volume that is expressed in parts per million $(\mathrm{mg} / \mathrm{L})$ or milligrams per unit volume. $\mathrm{pH}$ shows whether the sample is alkaline or acidic. It is a negative logarithm of hydrogen ion concentration. For $\mathrm{pH}$ measurement, GeNai pH digital meter $-117800 \mathrm{~GB}$ is used in the laboratory. It has pH range of 1-14 with $0.5 \pm 1$ digit accuracy $\mathrm{pH}$. [31-33].

\section{Estimation of radiological dose}

The annual effective dose due to ingestion and inhalation of $\mathrm{Rn}^{222}$ has been calculated using the parameters established in the reference [34,35].

The annual effective dose via ingestion can be calculated using the following equation2:

$$
E_{w . I g}\left(\mu S v \cdot y^{-1}\right)=C_{R_{n} w} \times C_{w} \times(E D C)
$$

Where, $E_{w . I g}$ is the annual effective ingestion dose, $C_{R_{n} w}$ is theRn ${ }^{222}$ activity concentration in water $(\mathrm{Bq} / \mathrm{L}), C_{w}$ is the estimation of water consumption for the average population $(600 \mathrm{~L} / \mathrm{y})$ and $E D C$ is the ingestion effective dose conversion coefficient i.e. $3.5 \mathrm{nSv} / \mathrm{Bq}$ [36]. Annual effective inhalation dose can be calculated by the equation 3 :

$$
E_{w \cdot I h}\left(\mu S v \cdot y^{-1}\right)=C_{R_{n} w} \times R_{a \cdot w} \times F \times O \times(D C F)
$$

Where, $E_{w . I h}$ is the annual effective inhalation dose, $C_{R_{n} w}$ is the $\mathrm{Rn}^{222}$ activity concentration in water $(\mathrm{Bq} / \mathrm{L}), R_{a . w}$ is the ratio of $\mathrm{Rn}^{222}$ in air and tap water $\left(10^{-4}\right)[36], F$ is the equilibrium factor between $\mathrm{Rn}^{222}$ and its progenies (0.4)[37], $O$ is average annual indoor occupancy time per person $(7000 \mathrm{~h} / \mathrm{y})$ and $D C F$ is the dose conversion factor due to $\mathrm{Rn}^{222}$ exposure i.e. 9 $\mathrm{nSv} /(\mathrm{h} .(\mathrm{Bq} / \mathrm{m} 3))[36]$.

Age-dependent annual effective ingestion dose was calculated using equation 4 as follows $[36,38]:$

$$
A E D_{\text {ing }}\left(\mu S v \cdot y^{-1}\right)=A \times w_{\text {ing }} \times D C F_{\text {ing }}
$$


182 Where, $A E D_{\text {ing }}$ is the age-dependent annual effective ingestion $\operatorname{dose}(\mu \mathrm{Sv} / \mathrm{y})$, A is the activity concentration of $\mathrm{Rn}^{222}$ in water $(\mathrm{Bq} / \mathrm{L}), w_{\text {ing }}$ is average annual water intake by the local population $\left(\mathrm{L} . \mathrm{y}^{-1}\right)$ and $D C F_{\text {ing }}$ is the age-dependent dose conversion factor $(\mathrm{nSv} / \mathrm{Bq})[39,40]$.

\section{Result and discussion}

The statistical parameters (i.e. minima, maxima, mean, standard deviation, skewness, and kurtosis) calculated for $\mathrm{Rn}^{222}$ activity concentration $(\mathrm{Bq} / \mathrm{L})$, TDS $(\mathrm{mg} / \mathrm{L}), \mathrm{pH}$, Electrical conductivity $(\mu \mathrm{S} / \mathrm{cm})$, age-dependent annual effective ingestion dose ( $\mu \mathrm{S} v / \mathrm{y})$, Annual effective ingestion dose ( $\mu \mathrm{Sv} / \mathrm{y})$, Annual effective inhalation dose $(\mu \mathrm{Sv} / \mathrm{y})$ and Total annual effective dose $(\mu \mathrm{Sv} / \mathrm{y})$ in Table 1.

\section{Radiological exposure due to $\mathrm{Rn}^{222}$ activity concentration in water}

193 The $\mathrm{Rn}^{222}$ activity concentrations in the water samples are found to be in the range of 0.6 to 81.9 $194 \mathrm{~Bq} / \mathrm{L}$ with a mean value of $17.8 \mathrm{~Bq} / \mathrm{L}$. These values are within the safe limit prescribed by WHO 195 (2008) and EU (2001a), that is $100 \mathrm{~Bq} / \mathrm{L}$ [41-42].

196 The frequency plot regarding the data obtained for $\mathrm{Rn}^{222}$ activity concentration in collected water samples is shown in Figure 3(a). The frequency plot indicates that more than half (54\%) of samples have $\mathrm{Rn}^{222}$ activity level below $10 \mathrm{~Bq} / \mathrm{L}$ and in $56 \%$ samples radon level is below 11.1 $\mathrm{Bq} / \mathrm{L}$ (recommended level by USEPA (1991)) [43]. All of samples have $\mathrm{Rn}^{222}$ levels within the safety limit recommended by WHO (2008). To obtain the best fit distribution among Lognormal, Exponential, Gamma and Weibull, K-S (modified) test and A-D test has been performed on

202 radon dataset, and goodness-of-fit statistical parameters are shown in Table 2. Results shown in table 2 and fig. 3 suggest that except exponential distribution, all other distributions (Lognormal,

204 Gamma and Weibull) captured the trend of the variation of the data. [44, 45]. Figure 3(b) 205 demonstrate the probability plot generated for the radon dataset. Lognormal, Gamma and 206 Weibull dataset lie over the fitted reference line, indicating good fit for the data. However, in the 207 Exponential probability plot, data points outreach the reference fitted line which indicates 208 rejection of Exponential distribution over the radon dataset. 


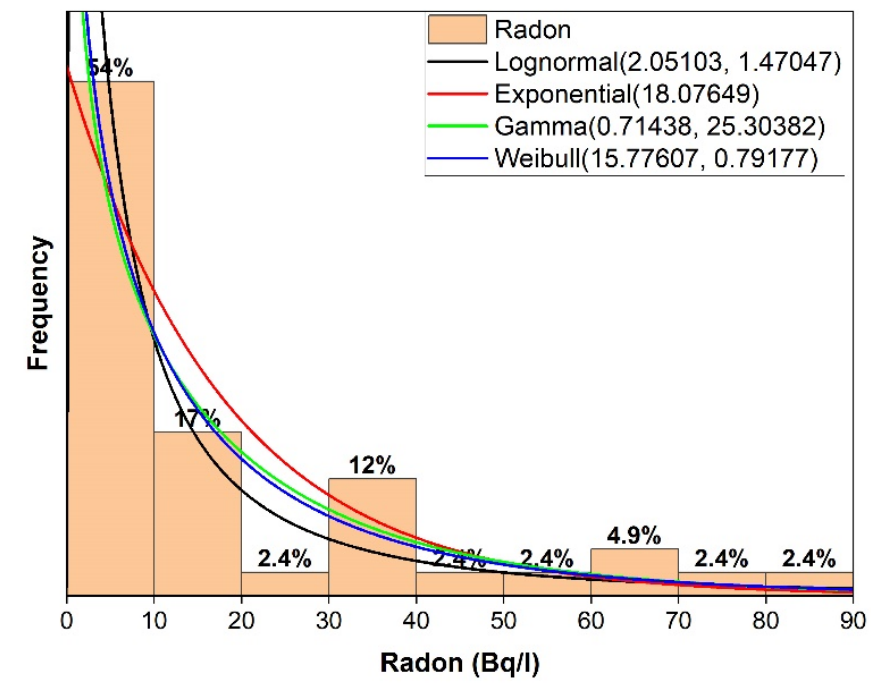

(a)
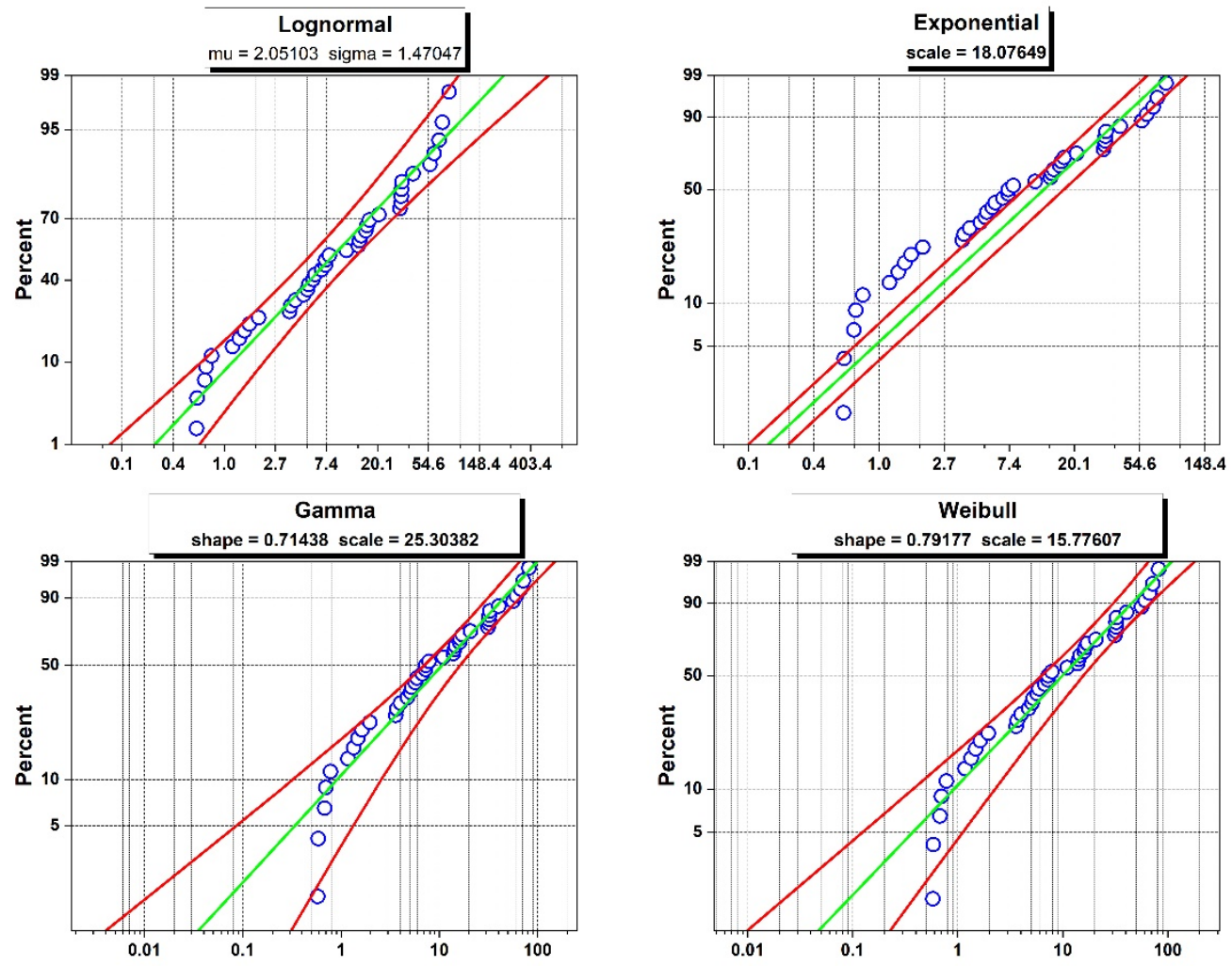

(b)

213 Figure 3: (a) Frequency plot and (b) probability plot of $R n^{222}$ activity concentration in water samples taken from Pithoragarh, district of Uttarakhand. 


\section{Physicochemical parameters}

216 Total dissolved solids (mg/L) values of the samples occur in the range between 18 and $434 \mathrm{mg} / \mathrm{L}$

217 with an average value of $148 \mathrm{mg} / \mathrm{L}$. From frequency plot (Fig 4a), it can be seen that; the TDS 218 concentration was below $50 \mathrm{mg} / \mathrm{L}$ in $37 \%$ samples and in 97\% samples its value was below 300

$219 \mathrm{mg} / \mathrm{L}$. Also shown in Table 1, this dataset is not uniform with -0.2 kurtosis and lightly-tailed or 220 non-uniformly random. Goodness-of-fit statistics using K-S (modified) and A-D test has been 221 performed over TDS dataset, and calculated parameters are shown in the Table 2 . The goodness-

222 of-fit statistics suggest that Lognormal, Gamma and Exponential distribution are not followed by 223 the TDS dataset. However, Weibull distribution is accepted as best fit among assumed 224 Distributions.

225 Figure 4(b) demonstrate the probability plot of the TDS dataset is rejected for Lognormal, 226 Gamma and Exponential distribution. However, it is observed that the K-S (modified) test 227 signifies that data-points are within the reference fitted line which confirms that Weibull 228 distribution is best fit for the dataset (Table 1), meanwhile Lognormal, Gamma and Exponential 229 distributions are rejected for the TDS dataset.

230 The $\mathrm{pH}$ values of collected samples range from 6.8 to 8.2 with a mean value of 7.2. Thus, the 231 samples are slightly alkaline but safe for drinking and other domestic purposes. Skewness and 232 kurtosis values show asymmetry of the dataset distribution which indicates a lack of external 233 parameters to affect the $\mathrm{pH}$ of the water samples. Electrical conductivity varies from $36 \mu \mathrm{S} / \mathrm{cm}$ to $234868 \mu \mathrm{S} / \mathrm{cm}$, with a mean value of $296 \mu \mathrm{S} / \mathrm{cm}$. 


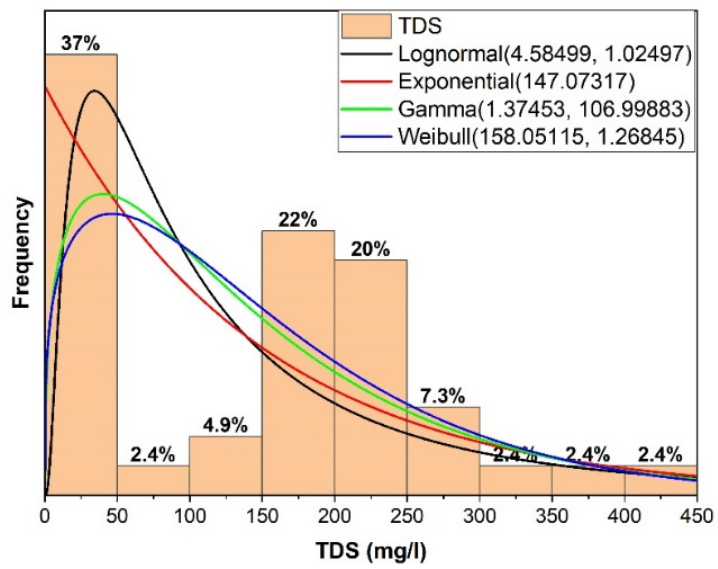

(a)


(b)

Figure 4: (a) Frequency plot and (b)probability plot of TDS present in the water samples taken 


\section{Radiological Dose assessment due to $\mathbf{R n}^{222}$ exposure}

244 The age-dependent annual effective ingestion dose ( $\left.\mathrm{AEI} \mathrm{I}_{\mathrm{g}} \mathrm{D}\right)$ estimated due to $\mathrm{Rn}^{222}$ exposure to 245 the local population is shown in Table 1. For infants (age below 1 year), the annual ingestion dose ( $\mu \mathrm{Sv} / \mathrm{y})$ varies from 2.7 to $376.6 \mu \mathrm{Sv} / \mathrm{y}$ with an average value of $81.7 \mu \mathrm{Sv} / \mathrm{y}$. These values

247 estimated for the children aged between 1 and 3 years vary within the range of $0.9-125 \mu \mathrm{Sv} / \mathrm{y}$ with an average value of $27.2 \mu \mathrm{Sv} / \mathrm{y}$. For children aged 4 to 8 years, the value of $\mathrm{AEI}_{\mathrm{g}} \mathrm{D}$ ranges



250 years, the average value of $\mathrm{AEI}_{\mathrm{g}} \mathrm{D}$ is $21.8 \mu \mathrm{Sv} / \mathrm{y}$ within the range of $0.7-100.3 \mu \mathrm{Sv} / \mathrm{y}$. For 251 teenagers (male) who come in the age group of 14 to 18 years, the range of $\mathrm{AEI} \mathrm{I}_{\mathrm{g}} \mathrm{D}$ occurs 252 between 1.2 and $171.9 \mu \mathrm{Sv} / \mathrm{y}$ with the mean value of $37.3 \mu \mathrm{Sv} / \mathrm{y}$. For the adults, the $\mathrm{AEI}_{\mathrm{g}} \mathrm{D}$ 253 ranges from 1.5 to $209 \mu \mathrm{Sv} / \mathrm{y}$ with an average value of $45.4 \mu \mathrm{Sv} / \mathrm{y}$. For Toddlers (female) aged 254 between 9 to 13 , the $\mathrm{AEI} \mathrm{g}$ values obtained within the range of $0.7-100.3 \mu \mathrm{Sv} / \mathrm{y}$ with an average 255 value of $21.8 \mu \mathrm{Sv} / \mathrm{y}$. The $\mathrm{AEI}_{\mathrm{g}} \mathrm{D}$ value for teenagers (female) ranges between 1.2 and $171.9 \mu \mathrm{Sv} / \mathrm{y}$ 256 with the mean value $37.3 \mu \mathrm{Sv} / \mathrm{y}$. For Adult females, the obtained values vary within the range of $257 \quad 1.5-209.2 \mu \mathrm{Sv} / \mathrm{y}$ with an average value of $45.4 \mu \mathrm{Sv} / \mathrm{y}$. The $\mathrm{AEI}_{\mathrm{g}} \mathrm{D}$ values for infants and children 258 are higher than for teenagers and adults because of the high value of dose conversion factors for 259 infants and children. High dose conversion factors for infants and children indicate that this age 260 group is at relatively higher risk due to similar exposure of $\mathrm{Rn}^{222}$ compared to other age groups. 261 For the study area, these dose values are well within the safe limits prescribed by various 262 agencies [41]. Therefore, water samplers analyzed for this region are safe for drinking for all age 263 groups. Figure 5 shows the violin plot for annual effective ingestion dose for the various age groups. The violin-like graph shows the kernel densities of the dataset of age-dependent annual

265 ingestion dose. The white dots between the densities are the median value. It can be seen that for 266 infants the median as well as the span of the dataset is highest. 


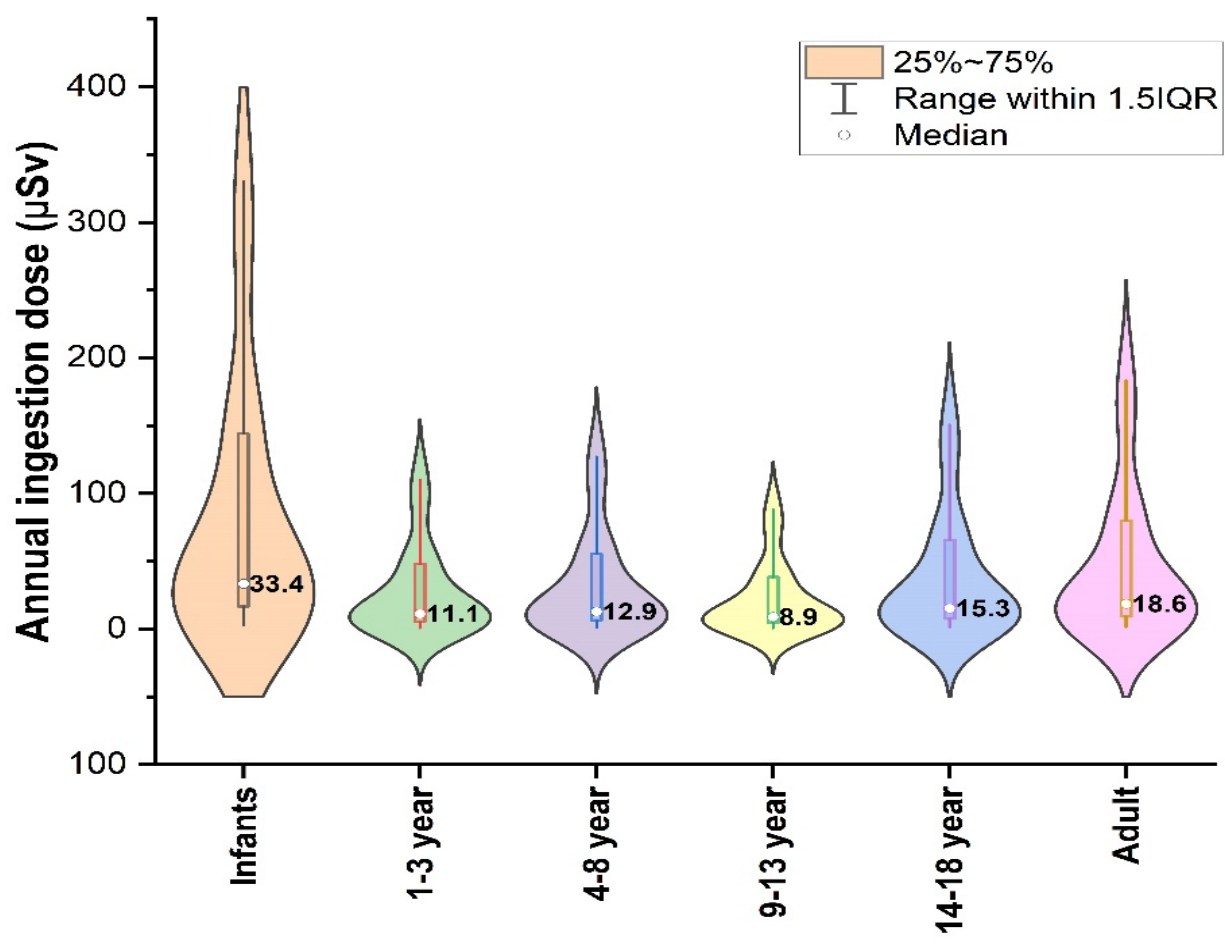

Figure 5: Violin plot of age-dependent annual effective ingestion dose.

269 The annual effective Ingestion dose $(\mu \mathrm{Sv} / \mathrm{y})$ due to $\mathrm{Rn}^{222}$ exposure through drinking water, 270 annual effective inhalation dose ( $\mu \mathrm{Sv} / \mathrm{y})$ due to inhalation of $\mathrm{Rn}^{222}$ escapes from the water and 271 total annual effective dose $(\mu \mathrm{Sv} / \mathrm{y})$ are also represented in Table 2 . The annual effective ingestion 272 dose ranges between 1.5 and $209.2 \mu \mathrm{Sv} / \mathrm{y}$ with the mean value $45.4 \mu \mathrm{Sv} / \mathrm{y}$. The annual effective 273 inhalation dose occurs in the investigation within the range of 1.8-258.2 $\mu \mathrm{Sv} / \mathrm{y}$ and the average 274 value is $56.0 \mu \mathrm{Sv} / \mathrm{y}$. The total annual effective dose due to $\mathrm{Rn}^{222}$ exposure ranges between 3.3 275 and $467.4 \mu \mathrm{Sv} / \mathrm{y}$ with a median value of $44.5 \mu \mathrm{Sv} / \mathrm{y}$. Figure 6 illustrates the violin plot of annual 276 effective ingestion dose $(\mu \mathrm{Sv} / \mathrm{y})$, annual effective inhalation dose $(\mu \mathrm{Sv} / \mathrm{y})$ and total annual 277 effective dose $(\mu \mathrm{Sv} / \mathrm{y})$, respectively. These values are under the recommended limits (WHO, 278 2004) for drinking water. The white dots in between quartiles indicate the mean value of the data 279 and the red line demonstrates the median value. The mean value is in the second quartile for all 280 the doses which usually happens when most of the data occur at low values. The total dose 281 increases when the $\mathrm{Rn}^{222}$ concentration increases. It is also demonstrated in the study that 282 although children drink less water than adults yet they receive more doses due to high dose 
conversion factor proposed for infants. Similar conclusions are also made by other studies in past $[35,39]$. No significant difference is found between AED for males and females.

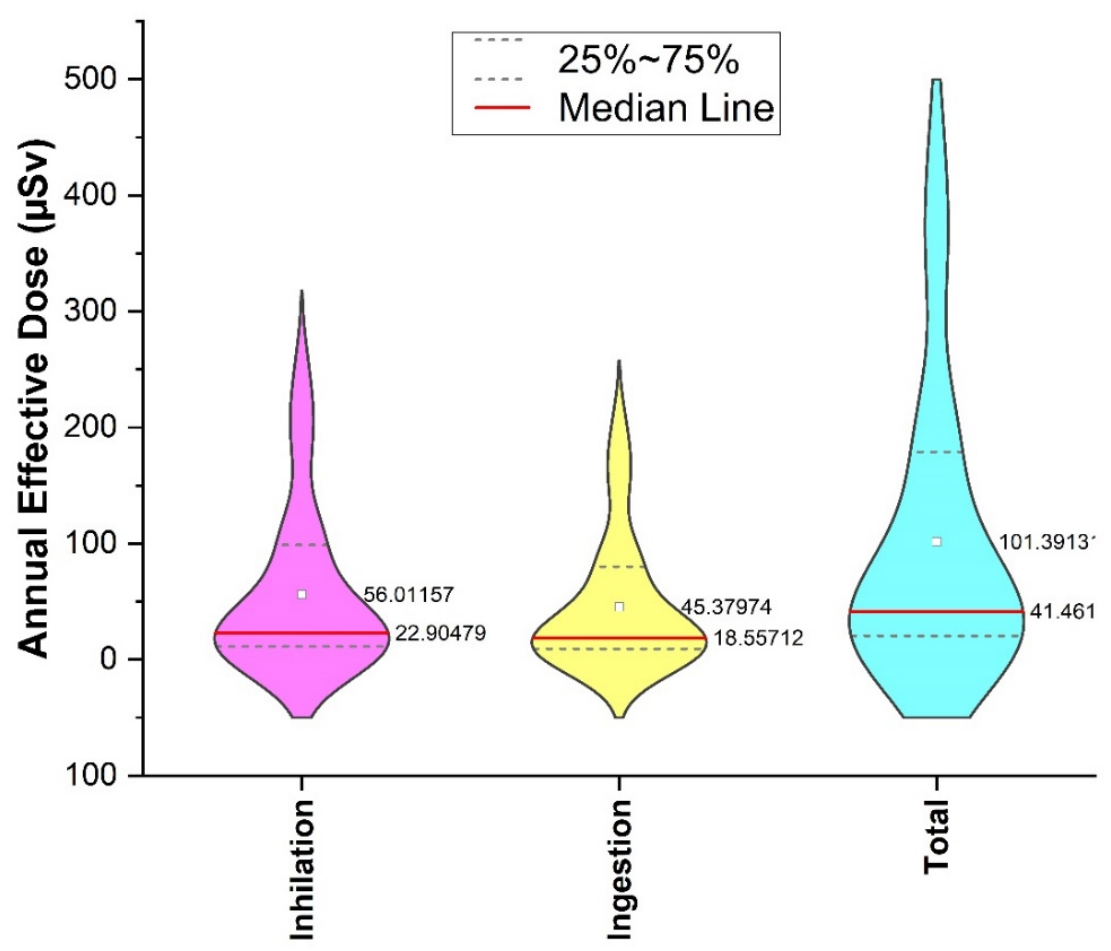

Figure 6: Violin plot for annual inhalation dose, annual ingestion dose and total annual effective dose.

\section{Spatial Analysis}

This study is a field survey; hence, it is imperative to analyze the dataset over terrestrial land, with available data points. QGIS 3.4 LTS software is used for spatial analysis of $\mathrm{Rn}^{222}$ activity concentration $(\mathrm{Bq} / \mathrm{L})$ and TDS $(\mathrm{mg} / \mathrm{L})$. It is to be noted that the sampling of water in the study was carried out on point locations of the map. The latitude and longitude were also taken by GARMIN-GPS during the measurement of the location of sampling. The pointwise data is not enough to illustrate areal distribution. Therefore, the inverse distance weighting (IDW) interpolation method is used to calculate the approximate values on the neighbouring locations where the data was not taken during fieldwork. It is an adaptive interpolation method that distributes the data values over a spatial area. The simplest weighting function that is used to 
interpolate data over the area is the inverse of the distance between two points with measured data on the location of sampling. This is a good method when need to apply for fewer location points otherwise kriging should be used for interpolation [46]. However, the accuracy of the predicted values for regions other than the sample nodes increases with the increase in sample size. The study represents the spatial distribution based on chosen data nodes only for indicative purposes.

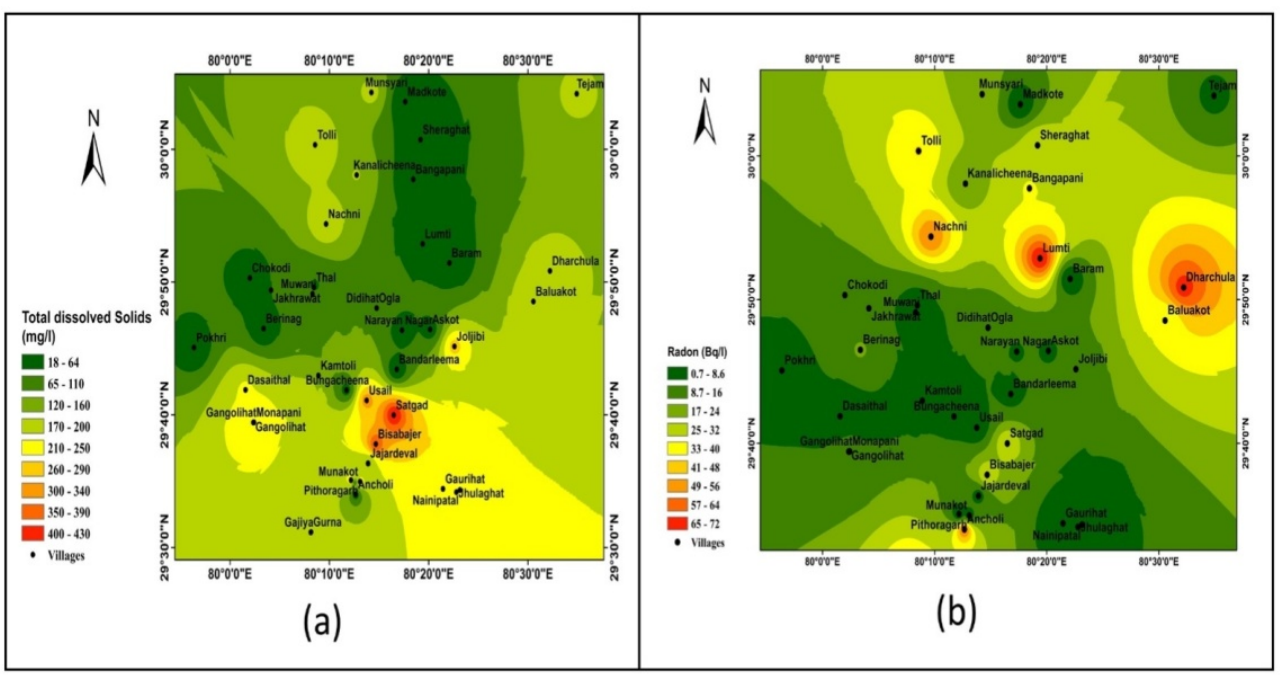

Figure 7: Spatial distribution of (a) TDS (mg/L) and (b)Rn $n^{222}$ activity concentration $(B q / L)$.

Figure 7 illustrate spatial distribution of TDS $(\mathrm{mg} / \mathrm{L})$ and $\mathrm{Rn}^{222}$ activity concentration $(\mathrm{Bq} / \mathrm{L})$. It is observed that the most of the samples show low values over the region for TDS ( $\mathrm{mg} / \mathrm{L}$ ) as well as $\mathrm{Rn}^{222}$ activity concentration $(\mathrm{Bq} / \mathrm{L})$. The water samples taken from the location of Usail, Satgad, Bisabajer and Jajardeval show comparatively higher values of TDS than other locations of the study area. The samples taken from the southern region have a TDS value of more than $160 \mathrm{mg} / \mathrm{L}$. Figure 7(b) demonstrates the predicted $\mathrm{Rn}^{222}$ activity concentration values in water samples for the study region. It is observed that the northern area shows high values of $\mathrm{Rn}^{222}$ activity concentration in water samples although TDS is comparatively lower than 200 $\mathrm{mg} / \mathrm{L}$ in the water samples taken from those nearby locations. The northern area of Pithoragarh is high altitude Terrain. More studies are needed to investigate higher $\mathrm{Rn}^{222}$ concentration values observed for high altitude regions. The observance of higher $\mathrm{Rn}^{222}$ activity concentration in low altitude regions (e.g. sampling node close to Dharchula) indicate the possibility of transportation of minerals by natural spring water, aquifers and rivers. 


\section{Conclusion}

In this study, 52 samples of drinking water were collected from Pithoragarh district of Uttarakhand, India. The samples were investigated for $\mathrm{Rn}^{222}$ activity concentration $(\mathrm{Bq} / \mathrm{L})$ level, TDS concentration $(\mathrm{mg} / \mathrm{L})$, Electrical Conductivity $(\mu \mathrm{S} / \mathrm{cm})$ and $\mathrm{pH}$. Age-dependent radiological doses to local population due to radon ingestion and inhalation due to water intake were also calculated and are compared with reference parameters recommended by ICRP (2002). All of the water samples have lower $\mathrm{Rn}^{222}$ activity concentration level than the reference limit recommended by European Commission (2001) and WHO (2008). The $\mathrm{Rn}^{222}$ activity concentration dataset follows Lognormal, Weibull and Gamma frequency distribution when tested with K-S (modified) and A-D tests for goodness-of-fit. Most of the samples have TDS below $250 \mathrm{mg} / \mathrm{L}$ which indicates that the samples are of good quality (mineral-wise). For the case of frequency distribution of TDS, Weibull distribution was found to be best fitted as per the tests for goodness-of-fit. On average, the tested water samples were found to be slightly alkaline. Higher age-dependent annual effective ingestion dose values for the infants reflect the impact of higher dose conversion factors. No significant difference was found between annual effective ingestion doses for males and females. The estimated dose values were found to be lower than the recommended levels, wherever applicable. The spatial distribution analysis demonstrated that the water samples from the southern region have higher TDS $(\mathrm{mg} / \mathrm{L})$ values and the Northern region have higher $\mathrm{Rn}^{222}$ activity concentration $(\mathrm{Bq} / \mathrm{L})$ levels. This study concludes that the springs and handpumps are the source of safe drinking water in Pithoragarh district of Uttarakhand, India.

\section{Acknowledgment}

The authors acknowledge the Board of Research in Nuclear Science (BRNS), Department of Atomic Energy (DAE)Project Ref. 36(4)/14/2016-BRNS, Mumbai, India, for extending their laboratory facilities for conducting the experimental work and funding for this research work.

\section{Declaration of Conflict of interest}

The authors declare that they have no known competing financial interests or personal relationships that could have appeared to influence the work reported in this paper. 
Journal of Radioanalytical and Nuclear Chemistry

348 
Journal of Radioanalytical and Nuclear Chemistry

Table 1: Statistical parameters of the measurements.

\begin{tabular}{|c|c|c|c|c|c|c|c|c|c|c|c|c|c|c|c|c|}
\hline \multirow{2}{*}{$\begin{array}{c}\text { Statistical } \\
\text { Parameters }\end{array}$} & \multirow{2}{*}{$\begin{array}{l}\text { Radon } \\
\text { Activity } \\
\text { Concentration } \\
(\mathrm{Bq} / \mathrm{L})\end{array}$} & \multirow{2}{*}{$\begin{array}{l}\text { TDS } \\
(\mathrm{mg} / \mathrm{L})\end{array}$} & \multirow{2}{*}{$\begin{array}{l}\text { EC } \\
(\mu \mathrm{S} / \mathrm{cm})\end{array}$} & \multirow{2}{*}{ pH } & \multicolumn{9}{|c|}{ Age-dependent Annual Effective Ingestion Dose $(\mu \mathrm{Sv} / \mathrm{y})$} & \multirow{2}{*}{$\begin{array}{l}\text { Annual } \\
\text { Effective } \\
\text { Inhalation } \\
\text { Dose } \\
(\mu \mathrm{Sv} / \mathrm{y})\end{array}$} & \multirow{2}{*}{$\begin{array}{l}\text { Annual } \\
\text { Effective } \\
\text { Ingestion } \\
\text { Dose } \\
(\mu \mathrm{Sv} / \mathrm{y})\end{array}$} & \multirow{2}{*}{$\begin{array}{l}\text { Total } \\
\text { Annual } \\
\text { Effective } \\
\text { Dose } \\
(\mu \mathrm{Sv} / \mathrm{y})\end{array}$} \\
\hline & & & & & Infants & $\begin{array}{l}1-3 \\
\text { Years }\end{array}$ & $\begin{array}{l}4-8 \\
\text { years }\end{array}$ & $\begin{array}{l}9-13 \\
\text { years }\end{array}$ & $\begin{array}{l}14- \\
18 \\
\text { years }\end{array}$ & Adults & $\begin{array}{l}\text { 9-13 } \\
\text { years } \\
\text { (female) }\end{array}$ & $\begin{array}{l}\text { 14-18 } \\
\text { years } \\
\text { (female) }\end{array}$ & $\begin{array}{l}\text { Adults } \\
\text { (female) }\end{array}$ & & & \\
\hline Minima & 0.6 & 18.0 & 36.0 & 6.8 & 2.7 & 0.9 & 1.0 & 0.7 & 1.2 & 1.5 & 0.7 & 1.2 & 1.5 & 1.8 & 1.5 & 3.3 \\
\hline Maxima & 81.9 & 434.0 & 868.0 & 8.2 & 376.6 & 125.6 & 144.9 & 100.3 & 171.9 & 209.2 & 100.3 & 171.9 & 209.2 & 258.2 & 209.2 & 467.4 \\
\hline Mean & 17.8 & 148.0 & 296.0 & 7.2 & 81.7 & 27.2 & 31.4 & 21.8 & 37.3 & 45.4 & 21.8 & 37.3 & 45.4 & 56.0 & 45.4 & 101.4 \\
\hline $\begin{array}{l}\text { Standard } \\
\text { Deviation }\end{array}$ & 21.4 & 107.0 & 214.0 & 0.3 & 98.4 & 32.8 & 37.9 & 26.2 & 44.9 & 54.7 & 26.2 & 44.9 & 54.7 & 67.5 & 54.7 & 122.1 \\
\hline Skewness & 1.5 & 0.5 & 0.5 & 0.2 & 1.5 & 1.5 & 1.5 & 1.5 & 1.5 & 1.5 & 1.5 & 1.5 & 1.5 & 1.5 & 1.5 & 1.5 \\
\hline Kurtosis & 1.7 & -0.2 & -0.2 & -1.1 & 1.7 & 1.7 & 1.7 & 1.7 & 1.7 & 1.7 & 1.7 & 1.7 & 1.7 & 1.7 & 1.7 & 1.7 \\
\hline
\end{tabular}


352 Table 2: Goodness of Fit statistics for $\mathrm{Rn}^{222}$ activity and TDS dataset in water samples.

353

\begin{tabular}{|c|c|c|c|c|c|}
\hline & Distribution & $\begin{array}{c}\text { Goodness of Fit } \\
\text { tests }\end{array}$ & Statistics & P-value & Decision at level (5\%) \\
\hline & Lognormal & K-S modified test & 0.075 & $>0.15$ & Accept Lognormal \\
\hline \multirow{7}{*}{$\begin{array}{l}\frac{\tau}{0} \\
\stackrel{0}{0} \\
\stackrel{\mathbb{x}}{0}\end{array}$} & & A-D test & 0.477 & 0.225 & Accept Lognormal \\
\hline & Weibull & K-S modified test & 0.099 & $>0.1$ & Accept Weibull \\
\hline & & A-D test & 0.456 & $>=0.25$ & Accept Weibull \\
\hline & Exponential & K-S modified test & 0.184 & 0.022 & Reject Exponential \\
\hline & & A-D test & 2.072 & 0.007 & Reject Exponential \\
\hline & Gamma & $\mathrm{K}-\mathrm{S}$ modified test & 0.117 & 0.235 & Accept Gamma \\
\hline & & A-D test & 0.566 & 0.180 & Accept Gamma \\
\hline \multirow{8}{*}{ 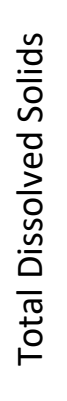 } & Lognormal & $\mathrm{K}-\mathrm{S}$ modified test & 0.215 & $<=0.01$ & Reject Lognormal \\
\hline & & A-D test & 2.494 & 2.04E-06 & Reject Lognormal \\
\hline & Weibull & $\mathrm{K}-\mathrm{S}$ modified test & 0.173 & $>0.1$ & Accept Weibull \\
\hline & & A-D test & 2.039 & $<0.01$ & Reject Weibull \\
\hline & Exponential & $\mathrm{K}-\mathrm{S}$ modified test & 0.193 & 0.014 & Reject Exponential \\
\hline & & A-D test & 1.873 & 0.012 & Reject Exponential \\
\hline & Gamma & $\mathrm{K}-\mathrm{S}$ modified test & 0.174 & 0.006 & Reject Gamma \\
\hline & & A-D test & 2.053 & $<0.005$ & Reject Gamma \\
\hline
\end{tabular}




\section{References}

[1] Cosma, C., Moldovan, M., Dicu, T., Kovacs, T. Radon in water from Transylvania (Romania). RADIATION MEASUREMENTS 43 pp. 1423-1428. , 6 p. (2008)

[2] Bajwa, B. S., Kumar, S., Singh, S., Sahoo, S. K., \& Tripathi, R. M. (2017). Uranium and other heavy toxic elements distribution in the drinking water samples of SW-Punjab, India. Journal of Radiation Research and Applied Sciences, 10(1), 13-19.

[3] Veiga, R., Sanches, N., Anjos, R. M., Macario, K., Bastos, J., Iguatemy, M., ... \&Umisedo, N. K. (2006). Measurement of natural radioactivity in Brazilian beach sands. Radiation measurements, 41(2), 189-196.

[4] El-Arabi, A. M. (2007). 226Ra, 232Th and 40K concentrations in igneous rocks from eastern desert, Egypt and its radiological implications. Radiation Measurements, 42(1), 94-100.

[5] Duggal, V., Sharma, S., \& Mehra, R. (2017). Radon levels in drinking water of Fatehabad district of Haryana, India. Applied Radiation and Isotopes, 123, 36-40.

[6] Kumar, A., Singh, P., Agarwal, T., Joshi, M., Semwal, P., Singh, K., ... \&Ramola, R. C. (2020). Statistical inferences from measured data on concentrations of naturally occurring radon, thoron, and decay products in Kumaun Himalayan belt. Environmental Science and Pollution Research, 27(32), 40229-40243.

[7] Semwal, P., Agarwal, T. K., Singh, K., Joshi, M., Gusain, G. S., Sahoo, B. K., \&Ramola, R. C. (2019). Indoor inhalation dose assessment for thoron-rich regions of Indian Himalayan belt. Environmental Science and Pollution Research, 26(5), 4855-4866.

[8] Ramola, R. C., Prasad, M., Kandari, T., Pant, P., Bossew, P., Mishra, R., \&Tokonami, S. (2016). Dose estimation derived from the exposure to radon, thoron and their progeny in the indoor environment. Scientific reports, 6(1), 1-16.

[9] Semwal, P., Singh, K., Agarwal, T. K., Joshi, M., Pant, P., Kandari, T., \&Ramola, R. C. (2018). Measurement of $222 \mathrm{Rn}$ and $220 \mathrm{Rn}$ exhalation rate from soil samples of Kumaun Hills, India. Acta Geophysica, 66(5), 1203-1211.

[10] Ramola, R.C., Choubey, V.M., Negi, M.S., Prasad, Y., Prasad, G. Radon occurrence in soil-gas and groundwater around an active landslide. Radiation Measurements, 2008, 43(1), pp. $98-101$ 
[11] Choubey, V.M., Bartarya, S.K., Ramola, R.C. Radon in Himalayan springs: A geohydrological control. Environmental Geology, 2000, 39(6), pp. 523-530.

[12] Ramola, R.C., Rawat, R.B.S., Kandari, M.S., Choubey, V.M. Measurement of radon in drinking water and indoor air. Radiation Protection Dosimetry, 1997, 74(1-2), pp. 103105

[13] Choubey, V. M., S. K. Bartarya, and R. C. Ramola. "Geological Controls on Radon in Soil and water of Pithoragarh region, Kumaun Himalaya, India." In Radon investigations in the Czech Republic XI and the 8th international workshop on the Geological Aspects of Radon Risk Mapping.-72-78, Czech Geol. Surv. Prague. 2006.

[14] Jobbagy, V., Kavasi, N., Somlai, J., Dombovari, P., Kardos, R., Kovacs, T. Radioanalytical investigations of uranium concentrations in natural spring, mineral, spa and drinking waters in Hungary. JOURNAL OF RADIOANALYTICAL AND NUCLEAR CHEMISTRY 286 : 2 pp. 417-422. , 6 p. (2010)

[15] Ramola, R.C., Choubey, V.M., Prasad, Y., Prasad, G., Bartarya, S.K. Variation in radon concentration and terrestrial gamma radiation dose rates in relation to the lithology in southern part of Kumaon Himalaya, India. Radiation Measurements, 2006, 41(6), pp. $714-720$

[16] Ramola, R.C., Choubey, V.M., Prasad, G., Gusain, G.S., Tosheva, Z., Kies, A. Radionuclide analysis in the soil of Kumaun Himalaya, India, using gamma ray spectrometry. Current Science, 2011, 100(6), pp. 906-914

[17] Bourai, A.A., Gusain, G.S., Rautela, B.S., Joshi, V., Prasad, G. and Ramola, R.C., 2012. Variations in radon concentration in groundwater of Kumaon Himalaya, India. Radiation protection dosimetry, 152(1-3), pp.55-57.

[18] Kumar, A., Singh, P., Semwal, P., Singh, K., Prasad, M. and Ramola, R.C., 2021. Study of primordial radionuclides and radon/thoron exhalation rates in Bageshwar region of Kumaun Himalaya, India. Journal of Radioanalytical and Nuclear Chemistry, pp.1-7.

[19] Duggal, V., Sharma, S., Srivastava, A. K., \& Mehra, R. (2018). Measurement of radon concentration in drinking water in Bhiwani district of Haryana. Journal of the Geological Society of India, 91(6), 700-703. 
[20] Sahoo B.K., Mayya Y.S, Sapra B.K., Gaware J.J. Banerjee K.S. and Kushwaha, H.S., 2010 Radon exhalation studies in an Indian Uranium tailings pile, Radiation Measurements, 45, pp. 237-241.

[21] Ajay, K., Manpreet, K., Rohit, M., Sumit, S., Rosaline, M., Singh, K. P., \&Bajwa, B. S. (2016). Quantification and assessment of health risk due to ingestion of uranium in groundwater of Jammu district, Jammu \& Kashmir, India. Journal of Radioanalytical and Nuclear Chemistry, 310(2), 793-804.

[22] Valdiya, K.S. 1980. Geology of Kumaun Lesser Himalaya. WIHG Publ. Dehra Dun. 291 pp.

[23] Valdiya, K. S. (1988). Tectonics and evolution of the central sector of the Himalaya. Philosophical Transactions of the Royal Society of London. Series A, Mathematical and Physical Sciences, 326(1589), 151-175.

[24] Chakraborty, C., Mandal, N., \& Ghosh, S. K. (2003). Kinematics of the Gondwana basins of peninsular India. Tectonophysics, 377(3-4), 299-324.

[25] Misra, R. C., \& Bhattacharya, A. R. (1976). The Central Crystalline Zone of northern Kumaun Himalaya: Its lithostratigraphy, structure and tectonics with special reference to plate tectonics. Him. Geol, 6, 133-154.

[26] Bhargava, O. N. (1980). Pre-Tertiary orogenies in the Himalaya: a review of various evidences. GeologischeRundschau, 69(3), 811-823.

[27] Prasad, Y., Prasad, G., Gusain, G.S., Choubey, V.M. and Ramola, R.C., 2009. Seasonal variation on radon emission from soil and water. Indian Journal of Physics, 83(7), pp.1001-1010.

[28] Gaware, J. J., Sahoo, B. K., Sapra, B. K., \&Mayya, Y. S. (2011). Indigenous development and networking of online radon monitors in the underground uranium mine. Radiation Protection and Environment, 34(1), 37.

[29] Singla, A. K., Kansal, S., \& Mehra, R. (2021). Quantification of radon contamination in drinking water of Rajasthan, India. Journal of Radioanalytical and Nuclear Chemistry, 327(3), 1149-1157.

[30] Kumar, M., Kaushal, A., Sahoo, B. K., Sarin, A., Mehra, R., Jakhu, R., ... \& Sharma, N. (2019). Measurement of uranium and radon concentration in drinking water samples and assessment of ingestion dose to local population in Jalandhar district of Punjab, India. Indoor and Built Environment, 28(5), 611-618. 
[31] Mueller, J. D., \&Rehder, G. (2018). Metrology of pH measurements in brackish waterspart 2: experimental characterization of purified meta-cresol purple for spectrophotometric pHT measurements. Frontiers in Marine Science, 5, 177.

[32] Qadir, R. W., Asaad, N., Qadir, K. W., Ahmad, S. T., \& Abdullah, H. Y. (2020). Relationship between radon concentration and physicochemical parameters in groundwater of Erbil city, Iraq. Journal of Radiation Research and Applied Sciences, 1-9.

[33] Jeyaraj, M., Indhuleka, A., \&Arunpaul, C. (2019). Investigation of Water Quality Index of River Noyyal and Its Connected Ponds Coimbatore Tamil Nadu India. Oriental Journal of Chemistry, 35(3), 1125.

[34] Mittal, S., Rani, A., \& Mehra, R. (2016). Radon levels in drinking water and soil samples of Jodhpur and Nagaur districts of Rajasthan, India. Applied Radiation and Isotopes, 113, 53-59.

[35] Ravikumar, P., \&Somashekar, R. K. (2014). Determination of the radiation dose due to radon ingestion and inhalation. International Journal of Environmental Science and Technology, 11(2), 493-508.

[36] United Nations Scientific Committee on the Effects of Atomic Radiation. (2000b). Sources, effects and risks of ionizing radiation, report to the general assembly with scientific annexes, United Nations, New York. 1, 126-127.

[37] UNSCEAR (1993) United Nations Scientific Committee on the effects of atomic radiation - sources and effects of ionizing radiation, 1993 report to the General Assembly, with scientific annexes. United Nation Sales Publication E.94.IX.2. United Nations, New York.

[38] International Commission on Radiological Protection. (2002). Guide for the practical application of the ICRP human respiratory tract model. ICRP supporting guidance 3. Oxford: Pergamon.

[39] Kaur, M., Tripathi, P., Choudary, I., Mehra, R., \& Kumar, A. (2017). Assessment of annual effective dose due to inhalation and ingestion of radon in water samples from some regions of Punjab, India. International Journal of Pure and Applied Physics, 13(2), 193200.

[40] Kumar, A., Arora, T., Singh, P., Singh, K., Singh, D., Pathak, P. P., \&Ramola, R. C. (2021). Quantification of radiological dose and chemical toxicity due to radon and 
uranium in drinking water in Bageshwar region of Indian Himalaya. Groundwater for Sustainable Development, 12, 100491.

[41] WHO (2008). Guidelines for drinking water quality. World Health Organization, Geneva. [42] European Commission. (2001). Commission recommendations of 20th December 2001 on the protection of the public against exposure to radon in drinking water. 2001, 2001/982/ Euratom, L344/85.

[43]USEPA (1991) United States Environmental Protection Agency-National primary drinking water regulations for radionuclides: notice of proposed rule-making. Fed Reg $56: 33050-33127$.

[44] Leon Harter, H., Khamis, H.J. and Lamb, R.E., 1984. Modified Kolmogorov-Smirnov tests of goodness of fit. Communications in Statistics-Simulation and Computation, 13(3), pp.293-323.

[45] Stephens, M. A. (1977). Goodness of Fit with Special Reference to Tests for Exponentiality, Technical Report No. 262, Department of Statistics, Stanford University, Stanford, CA.

[46]Lu, G. Y., \& Wong, D. W. (2008). An adaptive inverse-distance weighting spatial interpolation technique. Computers \& geosciences, 34(9), 1044-1055. 